\title{
Genetic diversity of Glycaspis brimblecombei (Hemiptera: Aphalaridae) and its parasitoid Psyllaephagus bliteus (Hymenoptera: Encyrtidae) in Brazil
}

\author{
F. A. Santos ${ }^{a *}$ (D), A. S. Correa (D) F. Nanini $^{b}$ (D), D. A. Nascimento ${ }^{a}$ (D), L. R. Junqueira ${ }^{c}$ (D) \\ and C. F. Wilcken ${ }^{a}$ iD \\ ${ }^{a}$ Universidade Estadual Paulista - UNESP, Faculdade de Ciências Agronômicas - FCA, Botucatu, SP, Brasil \\ 'Universidade de São Paulo - USP, Escola Superior de Agricultura "Luiz de Queiroz" - ESALQ, Piracicaba, SP, Brasil \\ 'Instituto de Pesquisas e Estudos Florestais - IPEF, Piracicaba, SP, Brasil \\ *e-mail: fabio.araujo@unesp.br
}

Received: October 28, 2019 - Accepted: February 14, 2020 - Distributed: August 31, 2021

(With 2 figures)

Eucalyptus plantations are attacked by exotic pests that decrease their productivity and burden the production chain. Global trade has contributed to the introduction of exotic pests in many countries and these pests are now a main concern of the forestry sector (Brockerhoff et al., 2006; Liebhold et al., 2012). Studies of the distribution patterns, genetic diversity, gene flow, and geographic origin of these pests are important to develop and implement pest-management programs in Eucalyptus plantations. Understanding the pests' origins and invasion patterns is essential to prevent future invasions (Wingfield et al., 2008; Nadel et al., 2010).

The red gum lerp psyllid, Glycaspis brimblecombei (Moore) (Hemiptera: Aphalaridae), is one of the main exotic pests of Eucalyptus in Brazil. This sap-sucking insect causes loss of photosynthetic area and dryness of the upper part of the crown, retarding trees growth. Severe attacks may even kill the trees (Wilcken et al., 2003). Glycaspis brimblecombei, originally from Australia, was first reported in California, USA in 1998 and in Mexico in 2000 (Brennan et al., 1999; Paine et al., 2006). Subsequently, G. brimblecombei was detected in Africa (Mauritius) and South America (Chile) in 2001, Brazil in 2003, and Europe in 2007, in the Iberian Peninsula (Wilcken et al., 2003; Olivares et al., 2004; Valente and Hodkinson, 2009). The most recent reports of $G$. brimblecombei invasions are in Ethiopia, New Zealand and Zambia (Chungu et al., 2017; Yirgu and Anjulo, 2019).

In Brazil, G. brimblecombei has been parasitized by the micro-wasp initially believed to be Psyllaephagus bliteus Riek (Hymenoptera: Encyrtidae). However, outbreaks of G. brimblecombei have coincided with low incidences of parasitism by $P$. bliteus in some parts of the country in recent years (Tuller et al., 2017). Understanding the diversity and possible genetic lineages of the pest and its parasitoid in different Brazilian regions can generate essential information to improve management of G. brimblecombei in Brazil. Our objectives were: (i) to evaluate the genetic diversity of $G$. brimblecombei and P. bliteus collected in different regions of Brazil; and (ii) to compare the mitochondrial genetic lineages from Brazil of G. brimblecombei and $P$. bliteus with previously identified genetic lineages from other regions of the world.

At least 20 specimens of $G$. brimblecombei were collected in Grajaú, Maranhão (05'52'29'’ 46 03'42'W), Três Lagoas, Mato Grosso do Sul (20³5'26'S 51 37'08' W), Itamarandiba, Minas Gerais (1753'18”S 42 51 '22'”'W), Telemaco Borba, Paraná (2417'47’S 50³7'10”W), Guaíba, Rio Grande do Sul (3008'57'S 51 $21^{\circ} 12^{\prime}$ 'W) and Botucatu, São Paulo (2250'44’S 48²6’04'W), Brazil. Psyllaephagus bliteus specimens were collected from Três Lagoas, Mato Grosso do Sul (20`35'26’S 51 37’08'W), Itamarandiba, Minas Gerais (17'53'18'S 42 51 '22”'W) and Botucatu, São Paulo (2250'44’S 48²6'04'W), Brazil. All specimens were collected from commercial Eucalyptus plantations and stored in $100 \%$ ethanol at $-20^{\circ} \mathrm{C}$. Total genomic DNA was extracted from adult insects, using the CTAB (cetyltrimethylammonium bromide) protocol, adapted from Doyle and Doyle (1990).

For G. brimblecombei, a fragment of the Cytochrome c Oxidase Subunit I (COI) gene fragment was amplified using the C1-J-2441 and TL2-N-3014 primers (Simon et al., 1994). For P. bliteus, a fragment of the Cytochrome B gene fragment was amplified using the CP1 and CB2 primers described by Harry et al. (1998) and Jermin and Crozier (1994), respectively. The samples were sent for Sanger bidirectional sequencing at the Center for Agricultural Biotechnology (CEBETC/ESALQ), University of São Paulo.

A consensus dataset of 517-bp COI fragments was generated for $34 \mathrm{G}$. brimblecombei individuals (4-7 individuals per collection site). We included in our dataset 13 sequences of individuals from $G$. brimblecombei from Portugal $(\mathrm{n}=5)$ and Australia ( $\mathrm{n}=8)$ (see Morrow et al., 2017). For P. bliteus, a 645-bp CytB fragment consensus dataset was generated for 12 individuals. Twenty-five sequences from different specimens of Psyllaephagus spp. (see Figure 1) were added to our dataset. The two datasets were individually aligned in MEGA X, using the ClustalW algorithm (Kumar et al., 2018). The sequences from Brazil were deposited at the NCBI 
GenBank under access numbers MN615705 and MN615706 - MN615707 for G. brimblecombei and Psyllaephagus, respectively. Inference of the number of haplotypes for each species was performed using the software DnaSP 5.10 (Librado and Rozas, 2009). For G. brimblecombei, we constructed a haplotype network using the PopArt software (Leigh and Bryant, 2015). For Psyllaephagus spp., we constructed a Bayesian phylogenetic tree using Mr. Bayes (Huelsenbeck and Ronquist, 2001), following the steps described by Oliveira et al. (2013).

A single G. brimblecombei haplotype (H1) was found in Brazil and is shared with individuals from Portugal (Figure 2). The three other haplotypes, H2, H3 and H4, are originated from Australia. Our results suggest that one G. brimblecombei invasion events occurred in Brazil and it was probably originated from locals previously invaded as USA, Mexico or Chile and not from Australia, origin geographic region, as already reported for other pests in Brazil (Nadel et al., 2010; Dittrich-Schröder et al., 2018; Bortolotto et al., 2019; Cordeiro et al., 2019; Ferronato et al., 2019).

The large genetic distance from the H4 haplotype to the other haplotypes suggests the presence of different G. brimblecombei genetic lineages in Australia, its region of origin (Figure 2). This result emphasizes the importance of phytosanitation planning to prevent the invasion of new G. brimblecombei genetic lineages into Brazil, since hybridization between different lineages could increase the adaptive potential of a pest and complicate efforts to suppress populations (Bertelsmeier and Keller, 2018; Corrêa et al., 2019).

We found two mitochondrial haplotypes/lineages among the individuals that were initially identified morphologically as P. bliteus in Brazil. When submitted to BLAST-NCBI (NCBI, 2019), the P1 haplotype showed high similarity to P. bliteus (homology $>99 \%$ ). However, the P2 haplotype showed $100 \%$ similarity to another species of Psyllaephagus from Australia (KU525267), which was not previously identified. The P1 haplotype identified as P. bliteus was found in four individuals collected from Botucatu and one from Itamarandiba. The P2 haplotype was found in four individuals from Três Lagoas and one individual from Botucatu. The Bayesian phylogenetic tree confirmed the presence of a high diversity of Psyllaephagus specimens in Australia, suggesting the occurrence of cryptic species that have not yet been taxonomically distinguished (Figure 1). The high diversity of the genus Psyllaephagus encourages prospecting for new natural enemies in Australia, to improve biological control of $G$. brimblecombei worldwide.

In conclusion, the presence of one haplotype in Brazil suggests that a single invasion event of $G$. brimblecombei originating from geographic areas previously invaded for this pest in the American continent. Furthermore, Brazil and Portugal share the same haplotype of G. brimblecombei, which shows a connection among invasion routes in the world. Finally, two distinct parasitoids species of the genus Psyllaephagus were found in Brazil, one them P. bliteus and the other one without taxonomic identification.

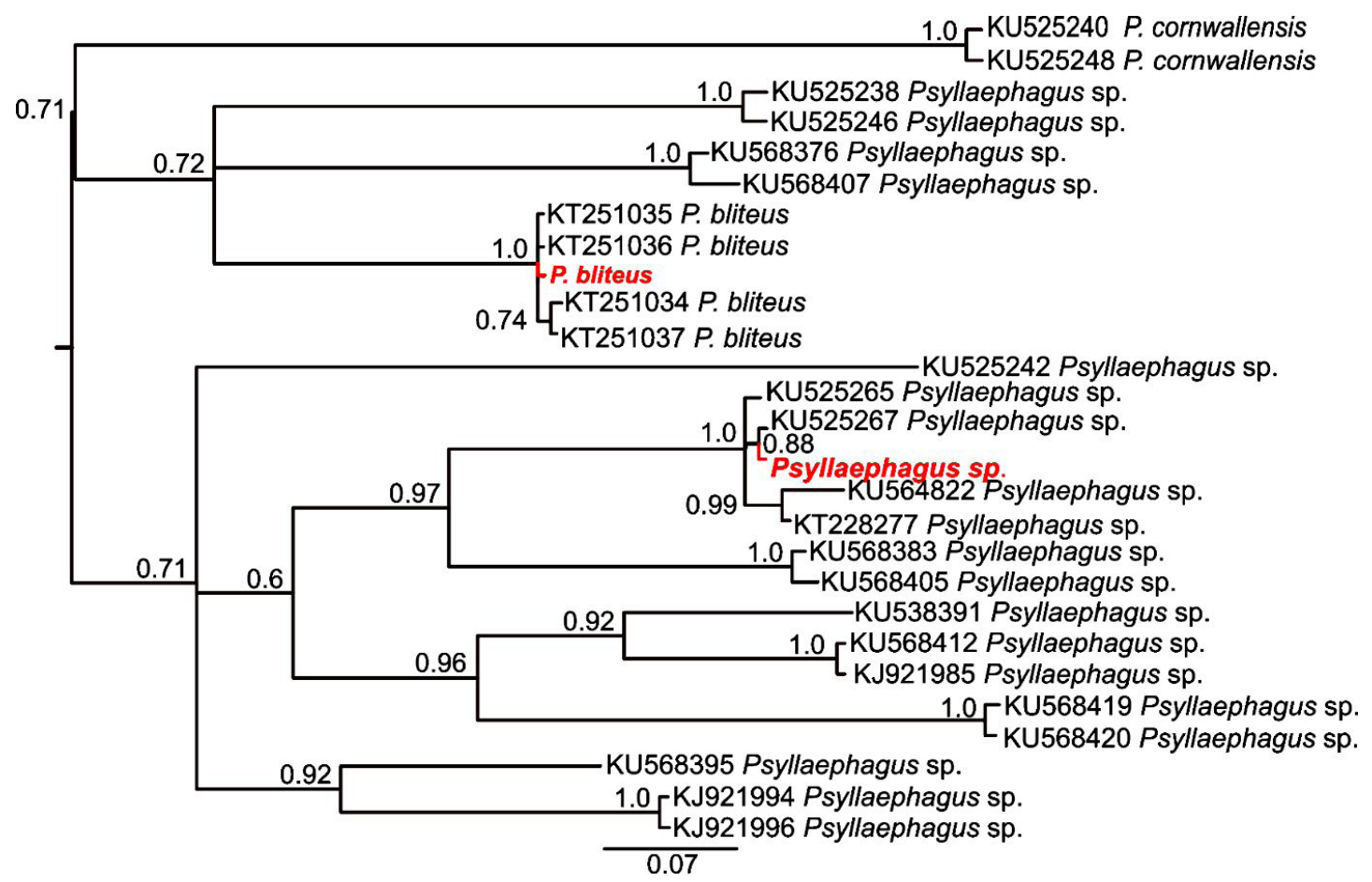

Figure 1. Bayesian phylogenetic tree of Psyllaephagus spp. based on the Cytochrome B gene fragment. 


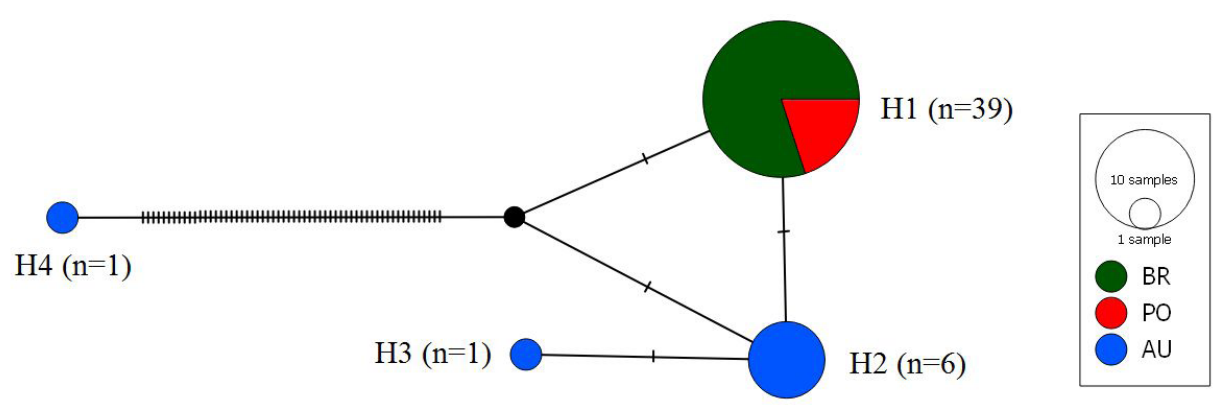

Figure 2. Haplotype network based on the Cytochrome c Oxidase Subunit I gene fragment for Glycaspis brimblecombei (Hemiptera: Aphalaridae) from Brazil (BR), Portugal (PO) and Australia (AU).

\section{Acknowledgements}

We thank the Coordenação de Aperfeiçoamento de Pessoal de Nível Superior - Brasil (CAPES) - Finance Code 001 and São Paulo Research Foundation (FAPESP, grant \#2014/11495-3). We also thank to the companies: Aperam, CMPC, Eldorado, IPEF and Suzano who helped with insect sampling.

\section{References}

BERTELSMEIER, C. and KELLER, L., 2018. Bridgehead effects and role of adaptive evolution in invasive populations. Trends in Ecology \& Evolution, vol. 33, no. 7, pp. 527-534. http://dx.doi. org/10.1016/j.tree.2018.04.014. PMid:29764688.

BORTOLOTTO, O.C., LUSTOSA, S.B.C. and PACENTCHUK, F., 2019. First report of Crocidosema (Epinotia) cosmoptila Meyrick, 1917 (Lepidoptera: Tortricidae) in Brazil. Brazilian Journal of Biology $=$ Revista Brasileira de Biologia, vol. 79, no. 4, pp. 749-750. http://dx.doi.org/10.1590/1519-6984.191299. PMid:30462816.

BRENNAN, E.B., GILL, R.J., HRUSA, G.F. and WEINBAUM, S.A., 1999. First record of Glycaspis brimblecombei (Moore) (Homoptera: Psyllidae) in North America: initial observations and predator associations of a potentially serious new pest of Eucalyptus in California. The Pan-Pacific Entomologist, vol. 75 , pp. 55-57.

BROCKERHOFF, E.G., LIEBHOLD, A.M. and JACTEL, H., 2006. The ecology of forest insect invasions and advances in their management. Canadian Journal of Forest Research, vol. 36, no. 2, pp. 263-268. http://dx.doi.org/10.1139/x06-013.

CHUNGU, D., SHAKACITE, O., CHAMA, H., CHUNGU, B.C., MBINDO, K. and MULONGWE, L., 2017. First record of the red gum lerp psyllid, Glycaspis brimblecombei Moore (Hemiptera: Psyllidae), in Zambia. African Journal of Ecology, vol. 55, no. 3, pp. 380-382. http://dx.doi.org/10.1111/aje.12353.

CORDEIRO, E.M.G., SOARES, P.L., ALVES, D.A. and CORRÊA, A.S., 2019. Updating the saga of the small hive beetle (Aethina tumida): molecular inference of the origin of the South American invasion. Apidologie, vol. 50, no. 3, pp. 273-276. http://dx.doi. org/10.1007/s13592-019-00636-5.

CORRÊA, A.S., CORDEIRO, E.M. and OMOTO, C., 2019. Agricultural insect hybridization and implications for pest management. Pest Management Science, vol. 75, no. 11, pp. 2857-2864. http://dx.doi.org/10.1002/ps.5495. PMid:31124266.
DITTRICH-SCHRÖDER, G., HOAREAU, T.B., HURLEY, B.P., WINGFIELD, M.J., LAWSON, S., NAHRUNG, H.F. and SLIPPERS, B., 2018. Population genetic analyses of complex global insect invasions in managed landscapes: a Leptocybe invasa (Hymenoptera) case study. Biological Invasions, vol. 20, no. 9, pp. 2395-2420. http://dx.doi.org/10.1007/s10530-018-1709-0.

DOYLE, J.J. and DOYLE, J.L., 1990. Isolation of plant DNA from fresh tissue. Focus, vol. 12, pp. 13-15.

FERRONATO, P., WOCH, A.L., SOARES, P.L., BERNARDI, D., BOTTON, M., ANDREAZZA, F., OLIVEIRA, E.E. and CORRÊA, A.S., 2019. A Phylogeographic Approach to the Drosophila suzukii (Diptera: Drosophilidae) Invasion in Brazil. Journal of Economic Entomology, vol. 112, no. 1, pp. 425-433. http://dx.doi.org/10.1093/jee/toy321. PMid:30383249.

HARRY, M., SOLIGNAC, M. and LACHAISE, D., 1998. Molecular evidence for parallel evolution of adaptive syndromes in figbreeding Lissocephala (Drosophilidae). Molecular Phylogenetics and Evolution, vol. 9, no. 3, pp. 542-551. http://dx.doi.org/10.1006/ mpev.1998.0508. PMid:9668003

HUELSENBECK, J.P. and RONQUIST, F., 2001. MRBAYES: bayesian inference of phylogenetic trees. Bioinformatics, vol. 17, no. 8, pp. 754-755. http://dx.doi.org/10.1093/bioinformatics/17.8.754. PMid:11524383.

JERMIN, L.S. and CROZIER, R.H., 1994. The cytochrome b region in the mitochondrial DNA of the ant Tetraponera rufoniger: sequence divergence in Hymenoptera may be associated with nucleotide content. Journal of Molecular Evolution, vol. 38, no. 3, pp. 282-294. http://dx.doi.org/10.1007/BF00176090. PMid:8006995.

KUMAR, S., STECHER, G., LI, M., KNYAZ, C. and TAMURA, K., 2018. MEGA X: Molecular Evolutionary Genetics Analysis across computing platforms. Molecular Biology and Evolution, vol. 35, no. 6, pp. 1547-1549. http://dx.doi.org/10.1093/molbev/ msy096. PMid:29722887.

LEIGH, J.W. and BRYANT, D., 2015. popart: full-feature software for haplotype network construction. Methods in Ecology and Evolution, vol. 6, no. 9, pp. 1110-1116. http://dx.doi. org/10.1111/2041-210X.12410.

LIBRADO, P. and ROZAS, J., 2009. DnaSP v5: a software for comprehensive analysis of DNA polymorphism data. Bioinformatics, vol. 25, no. 11, pp. 1451-1452. http://dx.doi. org/10.1093/bioinformatics/btp187. PMid:19346325.

LIEBHOLD, A.M., BROCKERHOFF, E.G., GARRETT, L.J., PARKE, J.L. and BRITTON, K.O., 2012. Live plant imports: the major pathways for forest insect and pathogen invasions of 
the US. Frontiers in Ecology and the Environment, vol. 10, no. 3, pp. 135-143. http://dx.doi.org/10.1890/110198.

MORROW, J.L., HALL, A.A. and RIEGLER, M., 2017. Symbionts in waiting: the dynamics of incipient endosymbiont complementation and replacement in minimal bacterial communities of psyllids. Microbiome, vol. 5, no. 1, pp. 58. http://dx.doi.org/10.1186/ s40168-017-0276-4. PMid:28587661.

NADEL, R.L., SLIPPERS, B., SCHOLES, M.C., LAWSON, S.A., NOACK, A.E., WILCKEN, C.F., BOUVET, J.P. and WINGFIELD, M.J., 2010. DNA barcoding reveals source and patterns of Thaumastocoris peregrinus invasions in South Africa and South America. Biological Invasions, vol. 12, no. 5, pp. 10671077. http://dx.doi.org/10.1007/s10530-009-9524-2.

NATIONAL CENTER FOR BIOTECHNOLOGY INFORMATION - NCBI, 2019 [viewed 28 October 2019]. BLAST-NCBI [online]. Available from: https://blast.ncbi.nlm.nih.gov/Blast.cgi

OLIVARES, T.S., BURCKHARDT, D.H. and CERDA, L.A., 2004. Glycaspis brimblecombei Moore, "Psyllido de los eucaliptos rojos" (Hemiptera: Psyllidae: Spondyliaspidinae): caracteres taxonómicos. Revista Chilena de Entomologia, vol. 30, pp. 5-10.

OLIVEIRA, M.R.C., CORRÊA, A.S., SOUZA, G.A., GUEDES, R.N.C. and OLIVEIRA, L.O., 2013. Mesoamerican origin and preand post-Columbian expansions of the ranges of Acanthoscelides obtectus Say, a cosmopolitan insect pest of the common bean. PLoS One, vol. 8, no. 7, pp. e70039. http://dx.doi.org/10.1371/ journal.pone.0070039. PMid:23936139.

PAINE, T.D., DREISTADT, S.H., GARRISON, R.W. and GILL, R.J., 2006. Eucalyptus redgum lerp psyllid. Pest Notes. Publ., vol. 7460, pp. 1-4.
SIMON, C., FRATI, F., BECKENBACH, A., CRESPI, B., LIU, H. and FLOOK, P., 1994. Evolution, weighting, and phylogenetic utility of mitochondrial gene sequences and a compilation of conserved polymerase chain reaction primers. Annals of the Entomological Society of America, vol. 87, no. 6, pp. 651-701. http://dx.doi.org/10.1093/aesa/87.6.651.

TULLER, J., OLIVEIRA, K.N., SILVA, J.O., DE FARIA, M.L., DO ESPÍRITO-SANTO, M.M., SERRÃO, J.E. and ZANUNCIO, J.C., 2017. Glycaspis brimblecombei (Hemiptera: Psyllidae) attack patterns on different Eucalyptus genotypes. PeerJ, vol. 5, pp. e3864. http://dx.doi.org/10.7717/peerj.3864. PMid:29085744.

VALENTE, C. and HODKINSON, I., 2009. First record of the redgum lerp psyllid, Glycaspis brimblecombei Moore (Hem.: Psyllidae), in Europe. Journal of Applied Entomology, vol. 133, no. 4, pp. 315-317. http://dx.doi.org/10.1111/j.1439-0418.2008.01324.x.

WILCKEN, C.F., COUTO, E. B., ORLATO, C., FERREIRA FILHO, P. J. and FIRMINO, D.C., 2003. Ocorrência do psilídeode-concha (Glycaspis brimblecombei) (Hemiptera: Psyllidae) em florestas de eucalipto no Brasil. Piracicaba: IPEF, pp. 1-11. Série Técnica IPEF, no. 201.

WINGFIELD, M.J., SLIPPERS, B., HURLEY, B.P., COUTINHO, T.A., WINGFIELD, B.D. and ROUX, J., 2008. Eucalypt pests and diseases: growing threats to plantation productivity. Southern Forests, vol. 70, no. 2, pp. 139-144. http://dx.doi.org/10.2989/ SOUTH.FOR.2008.70.2.9.537.

YIRGU, A. and ANJULO, A., 2019. First record of Glycaspis brimblecombei Moore (hem.: Psyllidae) on Eucalyptus camaldulensis in Ethiopia. Phytoparasitica, vol. 47, no. 1, pp. 67-70. http:// dx.doi.org/10.1007/s12600-018-00711-0. 